\title{
Leachates and elemental ratios of macrophytes and benthic algae of an Andean high altitude wetland
}

\author{
Florencia CUASSOLO*, Marcela BASTIDAS NAVARRO, Esteban BALSEIRO and Beatriz MODENUTTI \\ INIBIOMA (CONICET) - UNC Laboratorio de Limnología, Quintral 1250, 8400 Bariloche, Argentina \\ *e-mail corresponding author: cuassolof@comahue-conicet.gob.ar
}

\begin{abstract}
In wetlands, macrophytes and filamentous algae constitute an important carbon source for the total content of Dissolved Organic Matter (DOM) of the environment. Mallin wetland meadows are highly diverse and rare habitats in Patagonia, that can be characterized as wet meadows with a dense cover mainly dominated by herbaceous plants. We carried out a field study comparing elemental composition (C:N:P) of benthic algae (Spirogyra sp. and Zygnema sp.) and the submerged macrophyte (Myriophyllum quitense) from a high latitude wetland (local name: mallin). Besides we performed laboratory experiments in order to study the effect of ultraviolet radiation (UVR) on the optical properties and nutrient release of DOM from leachates of these benthic algae and submerged macrophyte. The obtained results indicated that macrophyte leachates could contribute significantly to changes in the optical characteristics of the wetlands while benthic algae contribute with leachates with low photoreactivity. Finally, nutrient release differs among plant species and season: benthic algae leachates release more $P$ in spring, while $\mathrm{M}$. quitense releases more of this nutrient in autumn. These results suggested that the different colonization may contribute differentially to the chemical environment of the wetland.
\end{abstract}

Key words: high altitude wetlands, submerged macrophytes, dissolved organic matter, carbon nitrogen phosphorus, ultraviolet radiation

\section{INTRODUCTION}

Patagonian wetlands occupy approximately a $5 \%$ of the total Patagonia area (Iriondo 1989). Among these there is a particular kind of wetland called by the Mapuche name mallin. These wetlands, which are similar to bogs, can be characterized as wet meadows with a dense cover mainly dominated by herbaceous plants belonging to families Juncaceae, Cyperaceae and Poaceae with a high net primary production (Raffaele 1999). Mallín wetland meadows are highly diverse habitats in western Patagonia (Raffaele 2004) and they are located either in steppe or forest environments in the Andes Cordillera. The steppe mallín wetlands are important resources for native and introduced species and in particular very significant for local economies based on cattle and sheep (Leon et al. 1998; Raffaele 1999; Hauenstein et al. 2002). On the contrary, mallín wetlands located in the mountains constituted flooded mountain meadows that are included in protected areas such as National Parks (Raffaele 2004), and protected from cattle grazing. However, due to their high altitude location, they are exposed to harsh environmental factors like ice and snow (provoking a shortage in plant growth) and high ultraviolet radiation (UVR). These wetlands are hydrologically complex environments (Iriondo et al. 1974), with the bottom covered by the submerged macrophyte Myriophyllum quitense (Ezcurra $\&$ Brion 2005), and filamentous benthic algae (Zygnema and Spirogyra). Although, there are studies regarding hydrology, seed banks, flora and fauna including microbial communities (Markgraf 1984; Raffaele 1996; Del Valle 1998; Cardoso et al. 2010), little is known about the elemental composition of plants, algae, and their leachates.

Macrophytes and filamentous algae constitute an important carbon source for the total content of dissolved organic matter (DOM) of wetlands (Wetzel 2001). These benthic producers release synthesized DOM during photosynthesis or through leaching of aged and dead tissues and filaments (Bertilsson \& Jones 2003). The DOM entering the aquatic environment can remain in the wetland water (Naiman \& Melillo 1984), and then be incorporated into the aquatic community through bacteria activity (Triska et al. 1989; Bastidas Navarro et al. 2009). On the other hand, DOM represents a significant component absorbing solar radiation in aquatic ecosystems, particularly in the ultraviolet region of the light spectrum (290 to $400 \mathrm{~nm}$ ) (Morris et al. 1995; Schindler \& Curtis 1997; Osburn et al. 2001). This energy absorption may lead to a variety of photochemical processes, including the photodegradation of DOM that could be related to changes in spectral and molecular properties (Bertilsson \& Tranvik 2000; Farjalla et al. 2001; Helms et al. 2008). In addition, UVR increases macrophyte degradation and leachate production (Mans et al. 1998; Anesio et al. 1999), and the photochemical processes may result in an important source and sink of essential nutrients such as nitrogen and phosphorus (Lewis 2002; Qualls \& Richardson 
2003). Since Patagonia is under the effect of the Antarctic ozone hole (Villafañe et al. 2001) a particular interest in these reactions rises from the increment of UVR caused by the reduction in the stratospheric ozone layer (Osburn et al. 2001; Zepp et al. 2003; Vernet 2006). Although there is lack of information about how UVR affects mallín wetlands dynamics, a strong effect of UVR on high altitude lakes of Patagonia was pointed out by previous studies (Zagarese \& Williamson 2000). Accordingly, an increase in DOM photobleaching due to increasing levels of UVR radiation was predicted (Osburn et al. 2001), and in turn the interaction of UVR with DOM can result in a nutrient source for aquatic microcommunities (Bastidas Navarro \& Modenutti 2010).

The importance of macrophyte and filamentous algae in wetland dynamics was recognized (Wigand et al. 2000; Egertson et al. 2004). However, the elemental constitution of these producers and how their leachates influence the optical properties of natural water by the input of DOM with different chemical features is still poorly known. This is of particular importance because it will affect the environmental nutrient cycling. In addition, as these environments are exposed to high UVR, a high interaction of short wavelength with this DOM coming from macrophytes and benthic algae is expected, resulting in important photochemical processes. Thus, our main hypothesis is that DOM will interact with UVR differentially according to the different sources. Because of its tissue complexity we expect that vegetal elemental composition and leachates of $M$. quitense will be richer in nutrients than those of Zygnema and Spirogyra. In order to test this hypothesis, we performed a field study to analyze the elemental composition of macrophytes and algae, and laboratory experiments analyzing the effect of UVR on DOM optical properties and nutrient release of their leachates.

\section{METHODS}

\subsection{Study Area}

The study was carried out in the mallín Los Patos located at an elevation of $1500 \mathrm{~m}$ above sea level, on the western slope of Cerro Chall-Huaco $\left(41^{\circ} 16^{\prime} \mathrm{S}\right.$ and $71^{\circ} 20^{\prime} \mathrm{W}$ ). The area is included in the Nahuel Huapi National Park, Patagonia, Argentina. At the centre of the meadow there are two streams, and on the western side there is a small pond (Area $=1.5$ ha) (Fig. 1). The surrounding vegetation is a subalpine forest of the deciduous Nothofagus pumilio (Poepp. et Endl.) Krasser. The flora of this wetland includes 52 native vascular species and 3 species of bryophytes (Raffaele 1993; Raffaele 1996). In particular, the pond is colonized by two aquatic plants: the emergent Carex subantarctica and the submerged Myriophyllum quitense, however the bottom is also covered by green filamentous algae of the genera Spirogyra and Zygnema.

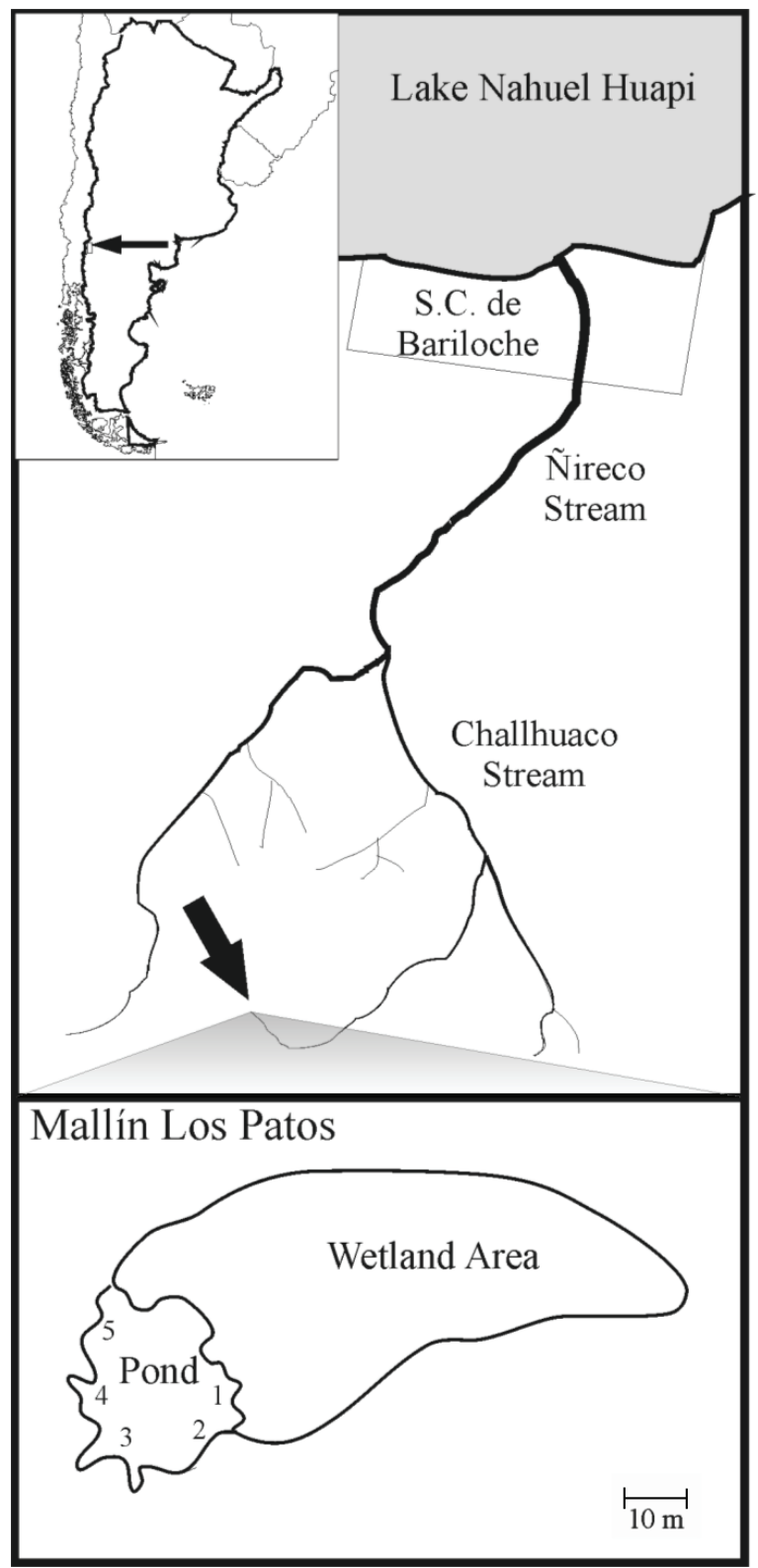

Fig. 1. Geographical location of study area. Numbers indicate the sampling points.

\subsection{Field study}

The pond was sampled on two different occasions: in late spring (December 2009) and autumn (April 2010) at 5 different sampling points (Fig. 1). Water temperature and dissolved oxygen were measured using an oxymeter (YSI Pro ODO Yellow Spring Instruments, USA), and $\mathrm{pH}$ was measured with a pH-meter (HI 8424 Hanna Instruments, USA). Redox potential was measured in the water, and in the sediments with a combined Pt electrode with $\mathrm{Ag} / \mathrm{AgCl}$ internal reference (HI-3131B Hanna Instruments). Water samples were obtained with a limnological bottle (2 L). Macrophytes and algae were sampled at each sampling point on each sampling occasion. The plants and algae were immediately carried to 
the laboratory in polyethylene bags. In addition, the vegetation cover was estimated by measuring directly the different areas covered by the different species.

\subsection{Laboratory procedures}

Total phosphorus (TP), total dissolved phosphorus (TDP) and total nitrogen (TN) in the pond water were determined according to APHA, (2005) and Valderrama (1981), and chlorophyll- $a$ concentration was determined according to Nusch (1980).

The elemental analysis of vegetal tissue and algae was carried out after carefully washing the vegetal material with distilled water. In Myriophyllum quitense the shoot and root parts were separated and dried at 60 ${ }^{\circ} \mathrm{C}$ for 48 hours up to a constant weight. Afterwards, dry plants and algae were crushed to powder with a clean mortar and approximately $2 \mathrm{mg}$ of dry weight (DW) was destined for elemental analysis. Carbon (C) and nitrogen $(\mathrm{N})$ concentration in the tissues were measured with a CN analyzer (Thermo Finnigan Flash EA 1112). Phosphorus was measured after combustion of $2 \mathrm{mg}$ DW of tissue at $450{ }^{\circ} \mathrm{C}$ during 1 hour followed by the ascorbate-reduced molybdenum method (Apha 2005).

Macrophyte and algae leachates were prepared with algae and plants collected in the field, which were carefully rinsed in distilled water and dried at room temperature. Finally, $1 \mathrm{~g}$ of algae or macrophyte was placed in $100 \mathrm{~mL}$ of MilliQ water and left there at $4{ }^{\circ} \mathrm{C}$ for $48 \mathrm{~h}$ following Anesio (2000). In order to eliminate any potential presence of bacteria in the samples all the glassware was sterilized, and the obtained water was filtered through precombusted $\mathrm{GF} / \mathrm{F}$ filter and then through sterile membrane filters of $0.2 \mu \mathrm{m}$ pore size. All glassware was previously cleaned with diluted clorhidric acid $(0.5 \mathrm{~N})$, rinsed with MilliQ water, and then combusted at $450{ }^{\circ} \mathrm{C}$ for 1 hour to make sure that it was carbon free. Similarly, the GF/F filters (Osmonics) were precombusted at $450{ }^{\circ} \mathrm{C}$ for 1 hour.

\subsection{Experimental design}

The optical features of algae and macrophyte leachates were studied in two experiments: Experiments 1 (late spring: December 2009) and 2 (autumn: April 2010). Both experiments consisted in the exposure of leachates of green filamentous algae and Myriophyllum quitense to different light treatments for four hours: (1) exposed to UVR+PAR, (2) exposed to PAR, and (3) DARK (wrapped in aluminium foil). Experiments were carried out in an incubator at $15 \pm 1{ }^{\circ} \mathrm{C}$ with a PAR intensity of $92 \mu \mathrm{mol} \mathrm{m}^{-2} \mathrm{~s}^{-1}$ (daylight fluorescent tubes). The UVR was provided by two UVA-340 fluorescent tubes (Q-Panel Lab Products, Cleveland, OH, U.S.A.). The UVR spectrum of these light tubes closely resembles the solar spectrum between 280 and $350 \mathrm{~nm}$ (Shick et al. 1999). During the incubation, water received 35 $\mu \mathrm{W} \mathrm{cm} \mathrm{nm}^{-1}$ of the $340 \mathrm{~nm}$ band, and this irradiance level is equivalent to surface noon summer sunlight in
Andean lakes. In the PAR treatment, UVR cutoff was reached using a polyethylene filter. The optical features of this polyethylene, with cutoff at $380 \mathrm{~nm}$ and $85 \%$ transmittance above $380 \mathrm{~nm}$, were checked before the experiment using a double-beam spectrophotometer Shimadzu UV 2450. Light exposure was carried out in $20 \mathrm{~mL}$ quartz tubes. Quartz tubes were distributed in a frame at $30 \mathrm{~cm}$ distance from the light source following Bertilsson \& Tranvik (2000). In both experiments, exposure was carried out in three replicates.

At the initial and final time of each experiment, spectrophotometric scans were carried out from $250 \mathrm{~nm}$ to $790 \mathrm{~nm}$ in $10 \mathrm{~cm}$ quartz cuvettes using a double-beam spectrophotometer Shimadzu UV2450. Dissolved Organic Carbon (DOC) was measured with a Shimadzu TOC VCSH carbon analyzer. For the nutrient release analysis, at initial and final time, Soluble Reactive Phosphorus (SRP) concentrations were obtained through the ascorbate-reduced molybdenum method.

\subsection{Data Analysis}

Absorbance units were converted to absorption coefficients $\left(a_{\mathrm{d}}\right)$. The ratio $a_{250}: a_{365}$ was used as a measure of the relative size of DOM molecules (Pérez \& Sommaruga 2006), and water color was determined as the absorbance coefficient at $440 \mathrm{~nm}\left(a_{440}\right)$ according to Pace \& Cole (2002).

Differences in limnological characteristics between spring and autumn were analyzed using a $t$-test. A Two Way ANOVA ("Plant" and "season" as factors) was applied in order to determine significant differences in optical characteristics and nutrient content between both leachates. Differences in elemental ratios, $a_{250}: a_{365}$ ratio, and SRP concentration were analyzed through a One Way ANOVA. Post hoc comparisons were made using the Tukey Test with an overall significance level of $p=$ 0.05 . All statistical analyses were performed using SigmaStat 3.1 and Statistica 6.0.

\section{RESULTS}

In Mallín Los Patos limnological features changed in the two sampling occasions (Tab. 1). Higher mean temperature values were recorded in spring $(t$-test, $p=$ 0.009 ) in coincidence with a lower dissolved oxygen concentration ( $t$-test, $p=0.202)$. Nevertheless, dissolved oxygen concentration was always near saturation $(85 \%$ in spring and $94 \%$ in autumn). Water redox potential exhibited high values in both water and sediments. Redox values in the water were significantly higher in spring ( $t$-test, $p=0.027$ ), while in the sediments no significant differences between seasons were observed $(t$-test, $p=0.189)$. In spring, there were higher dissolved organic carbon concentrations as well as higher water color values (high $a_{440}$ ), but lower mean molecular size (high $a_{250}: a_{365}$ ) (t-test, $p=0.023$ for DOC, $p \leq 0.001$ for $a_{440}$ and $a_{250}: a_{365}$ ). In spring also higher concentrations of TP, and TDP were observed ( $t$ - 


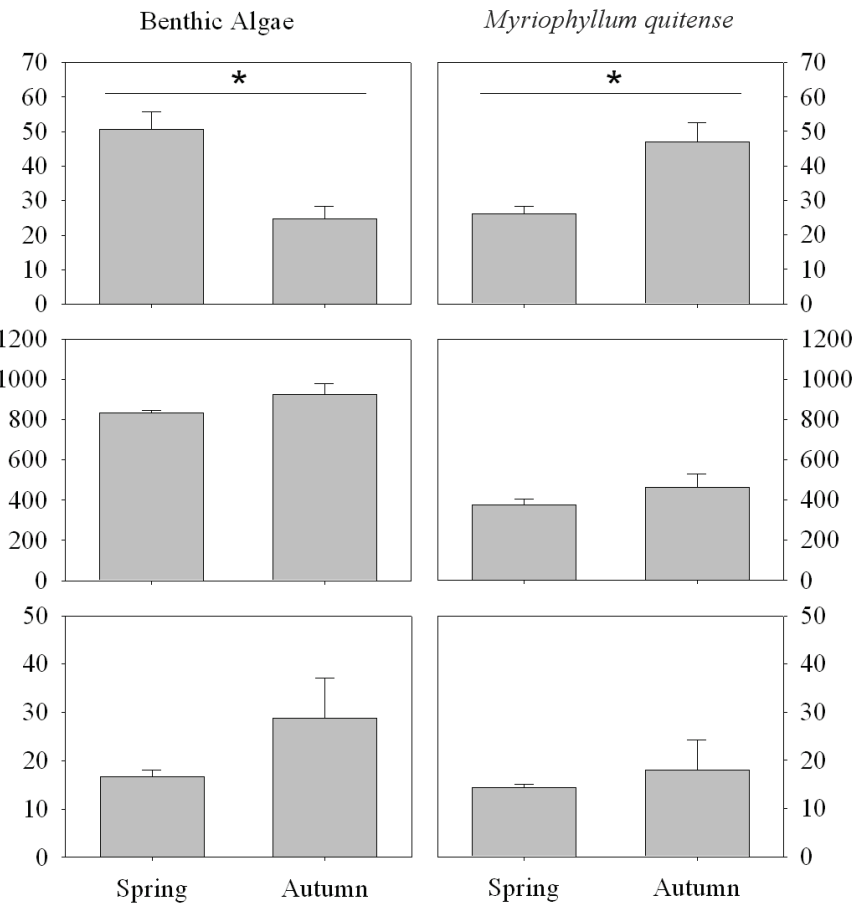

Fig. 2. Elemental relationships $(\mathrm{C}: \mathrm{N}, \mathrm{C}: \mathrm{P}$ and $\mathrm{N}: \mathrm{P}$ ratios) in the tissues of studied species in spring and autumn. (*) indicates significant differences $(p<0.05)$ between seasons.

test, $p<0.001$ for both cases). Finally, chlorophyll- $a$ concentrations were low in both seasons $\left(\approx 2.5 \mu \mathrm{g} \mathrm{L}{ }^{-1}\right)$, though significantly higher in autumn $(t$-test, $p<0.001)$ (Tab. 1).

Tab. 1. Limnological characteristics of Mallín Los Patos. Values are given as average \pm standard deviation.

\begin{tabular}{lcc}
\hline & Spring & Autumn \\
\hline Temperature $\left({ }^{\circ} \mathrm{C}\right)$ & $13.33 \pm 1.91$ & $7.55 \pm 1.88$ \\
Dissolved Oxygen $\left(\mathrm{mg} \mathrm{L}^{-1}\right)$ & $9.2 \pm 1.24$ & $11.3 \pm 2.27$ \\
$\mathrm{pH}$ & $6.51 \pm 0.83$ & $6.24 \pm 0.71$ \\
Redox Potential $(\mathrm{mV})($ water $)$ & $197 \pm 15.51$ & $114 \pm 43.61$ \\
Redox Potential $(\mathrm{mV})($ sediments $)$ & $275 \pm 80.10$ & $202 \pm 58.94$ \\
DOC $\left(\mathrm{mg} \mathrm{L}^{-1}\right)$ & $1.1 \pm 0.02$ & $0.4 \pm 0.08$ \\
$a_{250}: a_{365}$ & $3.50 \pm 0.10$ & $2.61 \pm 0.06$ \\
$a_{440}$ & $1.68 \pm 0.04$ & $1.08 \pm 0.03$ \\
TP $\left(\mu \mathrm{g} \mathrm{L}^{-1}\right)$ & $20 \pm 0.81$ & $8 \pm 0.06$ \\
TDP $\left(\mu \mathrm{g} \mathrm{L}^{-1}\right)$ & $8 \pm 0.34$ & $5 \pm 0.06$ \\
TN $(\mu \mathrm{g} \mathrm{L})$ & n.d. & $65 \pm 5.07$ \\
Chlorophyll- $a\left(\mu \mathrm{g} \mathrm{L}^{-1}\right)$ & $2 \pm 0.01$ & $3 \pm 0.05$ \\
\hline
\end{tabular}

The vegetation cover exhibited different patterns of spatial distribution between spring and autumn. During spring, the bottom coverage of $M$. quitense was about $80 \%$, while the benthic algae remained lower than $15 \%$. On the other hand, in autumn, benthic algae bottom coverage increased up to $60 \%$, whereas $M$. quitense constituted less than $30 \%$.

We observed differences in the elemental ratios between the studied species and seasons (Fig. 2). The $\mathrm{C}: \mathrm{N}$ ratio showed significant differences between seasons for both plants, while benthic algae (Spirogyra and Zygnema) exhibited higher values in spring ( $t$-test, $p=$
$0.007) M$. quitense showed higher ratios in autumn ( $t$ test, $p=0.025)$. On the other hand, the C:P elemental ratios showed no significant differences during both seasons for both plants ( $t$-test, $p=0.184$ for benthic algae, and $p=0.258$ for $M$. quitense). Benthic algae exhibited N:P ratio higher than 20, whereas the submerged macrophyte was always below 20 (Fig. 2) and this relationship remained similar during both seasons ( $t$-test, $p=0.280$ for benthic algae, and $p=0.613$ for $M$. quitense).

Leachates of both plants also presented differences in their optical and chemical features (Tab. 2). Benthic algae leachates exhibited lower values in the $a_{250}: a_{365}$ ratio indicating higher molecular size than in $M$. quitense (Two Way ANOVA, $p<0.001$ for "Species" factor, a posteriori Tukey test, $p<0.001$ ), and these values did not differ between seasons (Two Way ANOVA, $p=$ 0.363 for "Season" factor). We also observed differences in C (DOC) and P (SRP) in the two leachates, $M$. quitense being richer in $\mathrm{C}$ and $\mathrm{P}$ than benthic algae in both seasons (Two Way ANOVA, $p<0.001$, a posteriori Tukey test $p<0.001$ ) (Tab. 2).

Tab. 2. Optical features and nutrient content of leachates of the macrophyte and the benthic algae.

\begin{tabular}{lccccc}
\hline & \multicolumn{2}{c}{ Benthic Algae } & & \multicolumn{2}{c}{ M. quitense } \\
\cline { 2 - 3 } \cline { 5 - 6 } & Spring & Autumn & & Spring & Autumn \\
\hline$a_{250}: a_{365}$ & $3.00 \pm 0.05$ & $2.91 \pm 0.09$ & & $3.51 \pm 0.10$ & $3.52 \pm 0.03$ \\
$a_{440}$ & $2.19 \pm 0.01$ & $2.29 \pm 0.10$ & & $2.63 \pm 0.12$ & $3.68 \pm 0.01$ \\
DOC $\left(\mathrm{mg} \mathrm{g}^{-1}\right)$ & $58.4 \pm 0.05$ & $54.8 \pm 0.40$ & & $70.7 \pm 0.02$ & $90.4 \pm 0.68$ \\
SRP $\left(\mathrm{mg} \mathrm{g}^{-1}\right)$ & $3.4 \pm 0.29$ & $4.1 \pm 0.96$ & & $7.4 \pm 0.73$ & $7.8 \pm 0.21$ \\
\hline
\end{tabular}



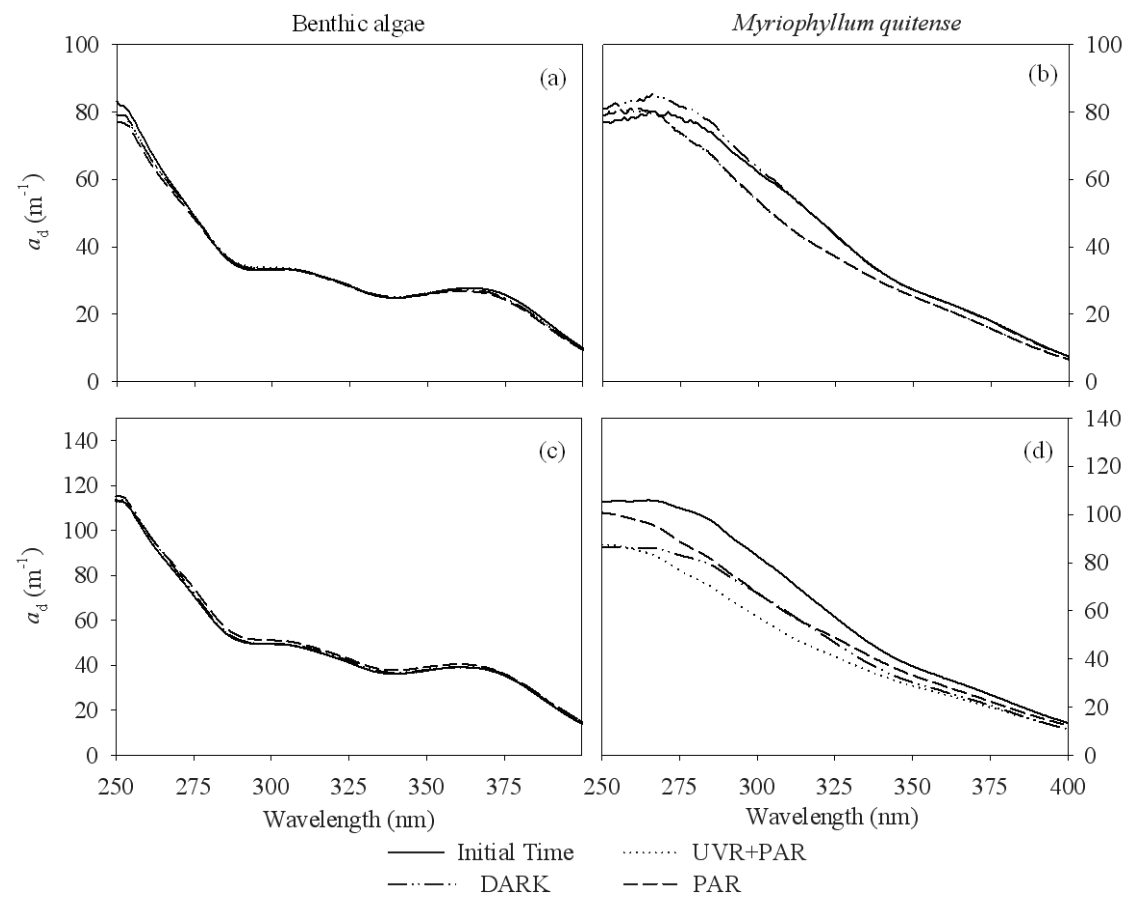

Fig. 3. Spectrophotometric absorbance curves in the leachates from benthic algae (left column) and Myiriophyllum quitense (right column) in spring (a and $\mathbf{b})$ and in autumn (c and $\mathbf{d})$ experiments.
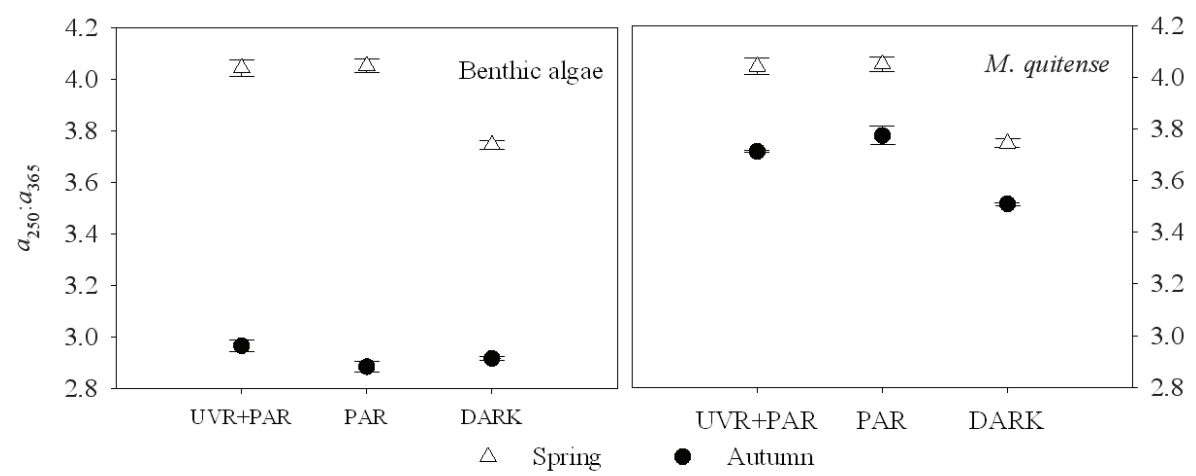

Fig. 4. Mean molecular weight $\left(a_{250}: a_{365}\right.$ ratio) in the leachates from benthic algae and Myiriophyllum quitense in both spring experiments.

In each species, in the two experiments the effect of light treatments on the optical features of the leachates showed similar trends (Fig. 3). Benthic algae leachates showed a bimodal pattern at the initial time, with maxima at $307 \mathrm{~nm}$ and at $370 \mathrm{~nm}$ (Fig. 3a and c); while M. quitense exhibited a unimodal spectrum with a maximum at $265 \mathrm{~nm}$ (Fig. $3 \mathrm{~b}$ and d). However, the leachates from benthic algae did not exhibit changes after UVR+PAR or PAR exposure neither in the spectrophotometric scans nor in the $a_{250}: a_{365}$ ratio (One Way ANOVA, $p=0.918$, Fig. 4), indicating a low photoreaction of this DOM to light exposure regardless of light quality. On the contrary, M. quitense leachates showed significant changes in the spectrophotometric scans and in the $a_{250}: a_{365}$ ratio between light treatments (One Way ANOVA, $p<0.001$ in both seasons, Fig. 4), with higher values in the UVR+PAR and PAR treatments (a posteriori Tukey test, $p<0.001$ for UVR $+\mathrm{PAR}$ and PAR vs DARK for both seasons).

Analyzing nutrient release by the leachates, we found that in the spring experiment benthic algae release more $\mathrm{P}$ in the DARK treatment (One Way ANOVA, $p=$ 0.002 , a posteriori Tukey test, $p<0.003$ for UVR+PAR and PAR vs DARK), while no significant differences were observed in the autumn experiment (One Way ANOVA, $p=0.078$ ) (Fig. 5a, b). On the contrary, we found that $M$. quitense in the spring experiment did not exhibit differences in P release (One Way ANOVA, $p=$ 0.176 , Fig. 5), while in the autumn experiment significant differences were observed (One Way ANOVA, $p$ $<0.001)$ with more $\mathrm{P}$ released in the DARK treatment (Fig. 5c, d). 

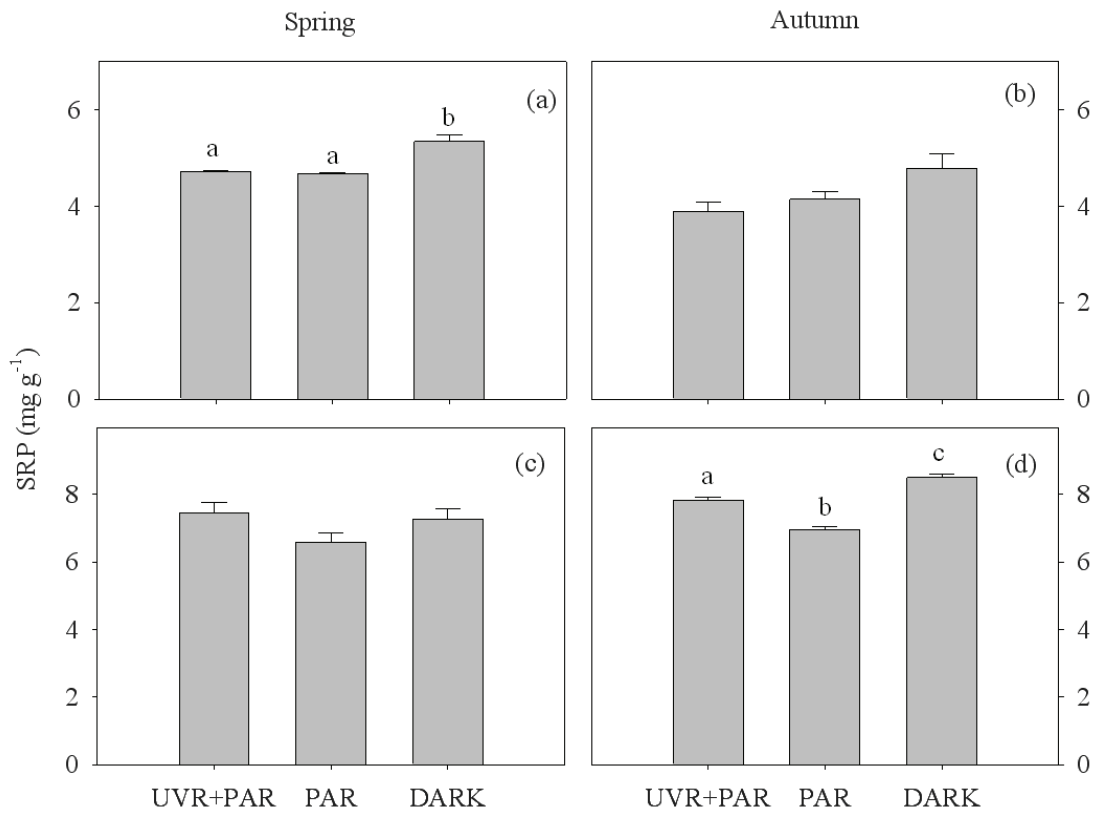

Fig. 5. SRP concentrations for benthic algae (a and b) and Myriophyllum quitense (c and d) in spring and autumn experiments. Letters on the bars indicate significant differences $(p<0.05)$ between light treatments (UVR+PAR, PAR and DARK).

\section{DISCUSSION}

Most lakes and many streams and rivers have a large proportion of their basins potentially available to macrophytes and epiphytes. Given the extent of habitat colonization and the high production rates (Moss 1998) macrophytes and benthic algae are important sources of dissolved organic matter (DOM) (Bertilsson \& Jones 2003). In Mallín Los Patos the whole bottom can be colonized by macrophytes and epiphytes; thus, these plants can be assumed to be very important for the ecosystem dynamics. In particular, our results showed that the submerged macrophyte Myriophyllum quitense and the green filamentous algae (Spirogyra and Zygnema) are important sources of dissolved organic carbon, providing about 55 and $80 \mathrm{mg} \mathrm{g}^{-1} \mathrm{DW}$ of benthic algae and M. quitense, respectively. These species also constitute a source of phosphorus that would be directly released to the water ( 3.75 and $7.58 \mathrm{mg} \mathrm{P} \mathrm{g}^{-1} \mathrm{DW}$ for benthic algae and $M$. quitense, respectively).

Interestingly, we determined that the dissolved oxygen concentration in water was near saturation, and aerobic conditions were also observed in the sediments (high redox potential) suggesting aerobic decomposition of organic matter in this environment. In wetlands, aerobic conditions are assumed to be determinants for mycrorrhizal fungi colonization (Daleo et al. 2007). The observed redox potential values in sediments may favor the development of mycorrhizal fungi. Thus, possible symbiotic associations would also play an important role in nutrient allocation in wetland macrophytes.

The C:N:P elemental ratios of the studied species showed differences that could be explained by species- specific relationships (Sterner \& Elser 2002; Demars \& Edwards 2007; Osborne \& Kovacic 2007). C:N:P stoichiometry of benthic microalgae has been indicated as largely variable in response to different levels and types of nutrient limitation (Hillebrand \& Sommer 1999). In our study, we observed that benthic algae C:N exhibited lower values in autumn, that can be associated with a higher growth and reproductive rate (González et al. 2010). On the contrary C:P elemental ratio did not vary in the two seasons. According to Loladze \& Elser (Loladze \& Elser 2011) N:P ratio higher than 16 implies a P limitation. The observed N:P ratios were around or over 20 suggesting that benthic algae are P limited. Thus, if algae are limited by nutrients, as it is often the case in natural conditions (Elser et al. 1990), other algae and bacteria may compete for them. In benthic algae, under $\mathrm{P}$ limitation, the $\mathrm{C}: \mathrm{P}$ ratios increased with decreasing growth rates and with higher growth when the ratio was around 130 (Hillebrand \& Sommer 1999). A different situation was observed for $M$. quitense, in which $\mathrm{N}: \mathrm{P}$ elemental ratio was below 20 though higher than 16, and C:N and C:P were higher in autumn, indicating a higher growth rate in spring. These results also support the differences observed in the cover of both plants, with dominance of benthic algae in autumn and of $M$. quitense in spring.

Different macrophyte species allocate nutrients differentially in their structural tissues, and therefore DOM coming from these species will have different nutrient content (Davis 1983). In that sense, we have hypothesized that the elemental composition and leachates of $M$. quitense would be richer in nutrients than those of benthic algae. Our results support this hypothesis, and in particular we observed a higher $\mathrm{P}$ release in autumn. 
However, we determined that benthic algae leachates released more $\mathrm{P}$ in spring than in autumn, suggesting that nutrient release sources could vary according to the alternative dominance of benthic algae and macrophytes.

Leachates are chemically heterogeneous compounds with labile and refractory fractions (Peret \& Bianchini 2004). The absorbance spectra obtained for benthic algae and $M$. quitense showed maximum absorbance at different wavelengths, suggesting that these plants have differences in the released DOM. Ultraviolet range (UV-A and UV-B), promotes the phototransformation of the DOM structure, molecular weight and optical properties (Reche et al. 2001; Brinkmann et al. 2003; Obernosterer \& Benner 2004), including nutrient release (Maranger \& Pullin 2003). Our laboratory experiments indicated that both leachates reacted differently to light. In autumn, benthic algae did not exhibit changes in spectrophotometric absorbance spectra or $a_{250}: a_{365}$ ratio, indicating that this DOM is mostly refractory. These results were consistent with the undetectable SRP release after light (UVR+PAR or PAR) exposure. It has been mentioned that in algae of high altitude lakes UVR promotes the accumulation of phenolic compounds (Figueroa et al. 2009). On the other hand, light treatments induced changes in the absorbance spectra of $\mathrm{M}$. quitense leachates and a decrease in the DOM mean molecular size after UVR and PAR exposure. This decrease of mean molecular size seemed to be related to a release of $\mathrm{P}$ after UVR exposure. Higher DOM photoreactivity has been observed in lakes with a high influence of autochthonous DOM (Reche et al. 2001). Similar results were obtained in field experiments in Lake El Trébol where natural lake water was exposed to solar radiation (Zagarese et al. 2001; Bastidas Navarro et al. 2009). However, other studies in shallow Andean lakes have indicated that leachates of Potamogeton linguatus and Schoenoplectus californicus macrophytes could contribute significantly to changes in the optical characteristics and nutrient release (Bastidas Navarro \& Modenutti 2010). However, our results indicate that the photoreactivity of autochthonous DOM is species dependent, since leachates of $M$. quitense seemed to react to light very similarly to other macrophyte species but the studied benthic algae exhibited a very low photoreactivity.

\section{CONCLUSIONS}

We observed that the elemental composition and leachates of the submerged macrophyte $M$. quitense were richer in nutrients than those of benthic algae and exhibited a higher $\mathrm{P}$ release in autumn. Besides, we determined that the colonization of wetlands by benthic algae will contribute with a DOM with lower photoreactivity than that of macrophytes. Finally, benthic algae leachates release more $\mathrm{P}$ in spring than in autumn, suggesting that nutrient release sources could vary accord- ing to the alternative dominance of benthic algae and macrophytes.

\section{ACKNOWLEDGEMENTS}

This work was supported by FONCyT PICT20071256 and PICT2007-1258. We thank Grace de Haro for English edition.

\section{REFERENCES}

Anesio, A.M., J. Theil-Nielsen \& W. Graneli. 2000. Bacterial growth on photochemically transformed leachates from aquatic and terrestrial primary producers. Microbial Ecology, 40: 200-208.

Anesio, A.M., L.J. Tranvik \& W. Granéli. 1999. Production of inorganic carbon from aquatic macrophytes by solar radiation. Ecology, 80: 1852-1859.

APHA. 2005. Standard methods for the examination of water and wastewater. American Public Health Association, AWWA.

Bastidas Navarro, M., E. Balseiro \& B. Modenutti. 2009. Effect of UVR on lake water and macrophyte leachates in shallow Andean-Patagonian lakes: bacterial response to changes in optical features. Photochemistry and Photobiology, 85: 332-340.

Bastidas Navarro, M. \& B.E. Modenutti. 2010. UVR induce optical changes and phosphorous release of lake water and macrophyte leachates in shallow Andean lakes. J. Limnol., 69: 112-119. DOI: 10.3274/JL10-69-1-10.

Bertilsson, S. \& J.B. Jones. 2003. Supply of Dissolved Organic Matter to aquatic Ecosystem: autochthonous sources. In: S.E.G. Findlay \& R. L. Sinsabaugh (Eds), Aquatic Ecosystems: Interactivity of Dissolved Organic Matter. Academic Press: 3-24.

Bertilsson, S. \& L.J. Tranvik. 2000. Photochemical transformation of dissolved organic matter in lakes. Limnol. Oceanogr., 45: 753-762.

Brinkmann, T., D. Sartorius \& F.H. Frimmel. 2003. Photobleaching of humic rich dissolved organic matter. Aquat. Sci., 65: 415-424.

Cardoso, B.M., E.E. Chaia \& E. Raffaele. 2010. Are Northwestern Patagonian "mallín" wetland meadows reservoirs of Ochetophila trinervis infective Frankia? Symbiosis, 52: 11-19.

Daleo, P., E. Fanjul, A.M. Casariego, B.R. Silliman, M.D. Bertness \& O. Iribarne. 2007. Ecosystem engineers activate mycorrhizal mutualism in salt marshes. Ecology Letters, 10: 902-908. 10.1111/j.1461-0248.2007.01082.x

Davis, C. \& A. Van der Valk. 1983. Litter decomposition in prairie glacial marshes. In G.R.D. Whigham \& R. Simpson (Eds), Freshwater Wetlands: Ecological Processes and Management Potential. Academic Press: 99-113.

del Valle, H.F. 1998. Patagonian soils: A regional synthesis. Ecología Austral, 8: 103-123.

Demars, B.O.L. \& A.C. Edwards. 2007. Tissue nutrient concentrations in freshwater aquatic macrophytes: high intertaxon differences and low phenotypic response to nutrient supply. Freshwat. Biol., 52: 2073-2086. DOI:10.1111/ j.1365-2427.2007.01817.x

Egertson, C.J., J.A. Kopaska \& J.A. Downing. 2004. A century of change in macrophyte abundance and composition in response to agricultural eutrophication. Hydrobiologia, 524: 145-156.

Elser, J., E. Marzolf \& C. Goldman. 1990. Phosphorus and nitrogen limitation of phytoplankton growth in the freshwaters of North America: a review and critique of experimental enrichments. Can. J. Fish. Aquat. Sci., 47: 14681477. 
Ezcurra, C. \& C. Brion. 2005. Plantas del Nahuel huapi. Primera ed. Universidad Nacional del Comahue \& Red Latinoamericana de Botánica: 70 pp.

Farjalla, V.F., A.M. Anesio, S. Bertilsson \& W. Granéli. 2001. Photochemical reactivity of aquatic macrophyte leachates: Abiotic transformations and bacterial response. Aquat. Microb. Ecol., 24: 187-195.

Figueroa, F.L., N. Korbee, P. Carrillo, J.M. Medina-Sánchez, M. Mata, J. Bonomi \& P. M. Sánchez-Castillo. 2009. The effects of UV radiation on photosynthesis estimated as chlorophyll fluorescence in Zygnemopsis decussata (Chlorophyta) growing in a high mountain lake (Sierra Nevada, Southern Spain). J. Limnol., 68: 206-216. DOI: 10.3274/JL09-68-2-05.

González, A.L., J.S. Kominoski, M. Danger, S. Ishida, N. Iwai \& A. Rubach. 2010. Can ecological stoichiometry help explain patterns of biological invasions? Oikos, 119: 779790. DOI:10.1111/j.1600-0706.2009.18549.x

Hauenstein, E., M. González, F. Peña-Cortes \& A. Muñoz-Pedreros. 2002. Flora and vegetation of coastal wetlands near Tolten, Chile. Clasificacion y caracterizacion de la flora y vegetacion de los humedales de la costa de Tolten (IX Region, Chile), 59: 87-100.

Helms, J., A. Stubbins, J. Ritchie, E. Minor, D. Kieber \& K. Mopper. 2008. Absorption spectral slopes and slope ratios as indicators of molecular weight, source, and photobleaching of chromophoric dissolved organic matter. Limnol. Oceanogr., 53: 955-969.

Hillebrand, H. \& U. Sommer. 1999. The nutrient stoichiometry of benthic microalgal growth: Redfield proportions are optimal. Limnol Oceanogr., 44: 440-446.

Iriondo, M. 1989. Quaternary lakes of Argentina. Palaeogeography, Palaeoclimatology, Palaeoecology, 70: 81-88.

Iriondo, M., J. Orellana \& M. Neiff. 1974. Sobre el concepto de mallín cordillerano. Revista de la Asociación Científico Naturalista Literario, 5: 45-52.

Leon, R.J.C., D. Bran, M. Collantes, J.M. Paruelo \& A. Soriano. 1998. Main vegetation units of the extra andean Patagonia. Grandes unidades de vegetacion de la Patagonia extra andina, 8: 125-144.

Lewis, W.M. 2002. Yield of nitrogen from minimally disturbed watersheds of the United States. Biogeochemistry, 57-58: 375-385. DOI:10.1023/a:1015709128245

Loladze, I. \& J.J. Elser. 2011. The origins of the Redfield nitrogen-to-phosphorus ratio are in a homoeostatic proteinto-rRNA ratio. Ecology Letters, 14(3): 244-250. DOI: 10.1111/j.1461-0248.2010.01577.x

Mans, C., T. Demvard \& L.J. Tranvik. 1998. Effects of solar radiation on aquatic macrophyte litter decomposition. Oikos, 82: 51-58.

Maranger, R. \& M. Pullin. 2003. Elemental complexation by dissolved organic matter in lakes: implications for $\mathrm{Fe}$ speciation and the bioavailability of $\mathrm{Fe}$ and $\mathrm{P}$. In: $\mathrm{S}$. Findlay \& R. Sinsabaugh (Eds), Aquatic ecosystems: interactivity of dissolved organic matter. Academic Press/Elsevier Science, San Diego, California, USA: 185214.

Markgraf, V. 1984. Late Pleistocene and Holocene vegetation history of temperate Argentina: Lago Morenito, Bariloche. Dissertations Bot., 72: 235-254.

Morris, D.P., H. Zagarese, C.E. Williamson, E.G. Balseiro, B.R. Hargreaves, B. Modenutti, R. Moeller \& C. Queimaliños. 1995. The attenuation of solar UV radiation in lakes and the role of dissolved organic carbon. Limnol. Oceanogr., 40: 1381-1391.

Moss, B. 1998. Ecology of fresh waters: man and medium, past to future. Wiley-Blackwell: $535 \mathrm{pp}$.

Naiman, R.J. \& J.M. Melillo. 1984. Nitrogen budget of a subarctic stream altered by beaver (Castor canadensis). Oecologia, 62: 150-155.
Nusch, E. 1980. Comparison of different methods for chlorophyll and phaeopigment determination. Arch. Hydrobiol. Beih., 14: 14-36.

Obernosterer, I. \& R. Benner. 2004. Competition between biological and photochemical processes in the mineralization of dissolved organic carbon. Limnol. Oceanogr., 49: $117-124$.

Osborne, L.L. \& D.A. Kovacic. 2007. Riparian vegetated buffer strips in water-quality restoration and stream management. Freshwat. Biol., 52: 243-258.

Osburn, C.L., D.P. Morris, K.A. Thorn \& R.E. Moeller. 2001. Chemical and optical changes in freshwater dissolved organic matter exposed to solar radiation. Biogeochemistry, 54: 251-278.

Pace, M. \& J. Cole. 2002. Synchronous variation of dissolved organic carbon and color in lakes. Limnol. Oceanogr., 47: 333-342.

Peret, A. \& I. Bianchini. 2004. Stoichiometry of aerobic mineralization $(\mathrm{O} / \mathrm{C})$ of aquatic macrophytes leachate from a tropical lagoon (São Paulo-Brazil). Hydrobiologia, 528: 167-178.

Pérez, M. \& R. Sommaruga. 2006. Differential effect of algaland soil-derived dissolved organic matter on alpine lake bacterial community composition and activity. Limnol. Oceanogr., 51: 2527-2537.

Qualls, R.G. \& C.J. Richardson. 2003. Factors controlling concentration, export, and decomposition of dissolved organic nutrients in the Everglades of Florida. Biogeochemistry, 62: 197-229.

Raffaele, E. 1993. Estructura y dinámica de la vegetación de un mallín de altura sometido a perturbaciones experimentales. Doctoral Dissertation. Universidad Nacional de La Plata, La Plata, Argentina: 116 pp.

Raffaele, E. 1996. Relationship between seed and spore banks and vegetation of a mountain flood meadow (Mallín) in Patagonia, Argentina. Wetlands, 16: 1-9.

Raffaele, E. 1999. Mallines: Aspectos generales y problemas particulares. In: M. AI (Ed.), Tópicos sobre Humedales Templados y Tropicales de Sudamérica. UNESCO: 27-33.

Raffaele, E. 2004. Susceptibility of a Patagonian mallín flooded meadow to invasion by exotic species. Biological Invasions, 6: 473-481.

Reche, I., E. Pulido-Villena, J.M. Conde-Porcuna \& P. Carrillo. 2001. Photoreactivity of dissolved organic matter from high-mountain lakes of Sierra Nevada, Spain. Arctic, Antarctic, and Alpine Research, 33: 426-434.

Schindler, D. \& P. Curtis. 1997. The role of DOC in protecting freshwaters subjected to climatic warming and acidification from UV exposure. Biogeochemistry, 36: 1-8.

Shick, J.M., S. Romaine-Lioud, C. Ferrier-Pagès \& J.P. Gattuso. 1999. Ultraviolet-B radiation stimulates shikimate pathway-dependent accumulation of mycosporine-like amino acids in the coral Stylophora pistillata despite decreases in its population of symbiotic dinoflagellates. Limnol. Oceanogr., 44: 1667-1682.

Sterner, R. W. \& J. J. Elser. 2002. Ecological stoichiometry. The biology of elements from molecules to the biosphere. Princeton University Press: 439 pp.

Triska, F.J., V.C. Kennedy, R.J. Avanzino, G.W. Zellweger \& K.E. Bencala. 1989. Retention and transport of nutrients in a third-order stream: channel processes. Ecology, 70: 1877-1892.

Valderrama, J.C. 1981. The simultaneous analysis of total nitrogen and total phosphorus in natural waters. Marine Chemistry, 10: 109-122.

Vernet, M. 2006. Introduction: Enhanced UV-B radiation in natural ecosystems as an added perturbation due to ozone depletion. Photochemistry and Photobiology, 82: 831-833.

Villafañe, V.E., E.W. Helbling \& H.E. Zagarese. 2001. Solar ultraviolet radiation and its impact on aquatic systems of Patagonia, South America. Ambio, 30: 112-117. 
Wetzel, R. 2001. Limnology: lake and river ecosystems. Academic Press San Diego, CA: 850 pp.

Wigand, C., J. Wehr, K. Limburg, B. Gorham, S. Longergan \& S. Findlay. 2000. Effect of Vallisneria americana (L.) on community structure and ecosystem function in lake mesocosms. Hydrobiologia, 418: 137-146.

Zagarese, H. \& C. Williamson. 2000. Impact of solar UV radiation on zooplankton and fish. In: S. de Mora, S. Demers $\& \mathrm{M}$. Vernet (Eds), The effects of UV radiation in the marine environment. Cambridge University Press: 279-309.

Received: February 2011

Accepted: March 2011
Zagarese, H.E., M. Diaz, F. Pedrozo, M. Ferraro, W. Cravero \& B. Tartarotti. 2001. Photodegradation of natural organic matter exposed to fluctuating levels of solar radiation. Journal of Photochemistry and Photobiology B: Biology, 61: 35-45.

Zepp, R.G., T.V. Callaghan \& D.J. Erickson Iii. 2003. Interactive effects of ozone depletion and climate change on biogeochemical cycles. Photochemical and Photobiological Sciences, 2: 51-61. 